\title{
Energy Efficiency Labelling System for Industrial Motors
}

\author{
T. Pirathapan ${ }^{1}$, Tharanga Wickramarathna ${ }^{2}$ \\ Electrical Superintendent ${ }^{1}$, Electrical Engineer 2, Ceylon Electricity Board
}

\begin{abstract}
This paper presents an energy efficiency labelling system for industrial motors used in Sri Lanka. Industrial sector in Sri Lanka consumes 3,880 GWh of electricity, i.e. $33 \%$ out of 11,741 GWh of total electricity consumption (2015). Induction motors account for a high share of energy used in industry. The energy efficiency labelling system proposed will enable improved efficiency of industrial motors by reducing energy losses.

The automatic efficiency testing program is developed using the LabView development platform based on IEC 60034-2-1 standard. Subsequently, a test bench design was also developed. It will be helpful in purchasing motors from the international market and thereby motor driven systems will achieve the next level of efficiency in the industrial sector. It also helps to cross check the efficiency level of repaired or rewound motors. An economic calculation model (tariff based) is developed to analyse the economic benefits of higher efficiency levels. This economic calculation model assists in decision-making of replacement of a motor or an upgrade of a system.
\end{abstract}

\section{Introduction}

Electric motors account for about $60 \%$ of the industrial electricity consumption and about $15 \%$ of final energy use in industry worldwide [12].

Electric motor is the main source to provide mechanical energy in industry. Motor sizes vary between less than $1 \mathrm{~kW}$ to several MW in large industrial motors. In recent years, many studies have identified that there is a considerable energy efficiency potential with short payback periods and high cost-effectiveness in electric motors and motor systems used in industries.

Electric motors are the most prevalent energy intensive machines used in industries in Sri Lanka. These motors have long years of service, more than 20 years in some factories, and are mostly refurbished, and repaired and/or rewound several times. As a result of such refurbishments, efficiency is generally reduced. The low efficiency of electric motors affects the electric power supply infrastructure by unnecessarily demanding higher capacity, causing overloading, outages and voltage drops in the utility network. Further, the increase of the electricity consumption affects the electricity costs. Electricity utilities Ceylon Electricity Board (CEB)/Lanka Electricity Company (LECO) too pay for the wasted energy, which finally affects the sustainability of the environment.

Reasons for lower energy efficiency of electric motors are design limitations, poor quality of power supply, inadequate maintenance and repair practices, and the mismatch between motor and motor loads.

Motor manufacturing standards such as NEMA and IEC, and motor test standards such as IEC 60034-21, IEEE 112B and CSA 390 were studied. Such internationally recognized standards encourage users to buy energy efficient motors and encourage manufactures to produce electric motors complying with the standards. The development of motor labelling programs, motor efficiency standards and motor efficiency testing protocols different around the world. Some examples are, Brazil: NBR5383-1, India: IS 4889, China: GB/T C 1032, and Australia/New Zealand: AS NZS 1359.5. All these standards are similar to IEEE 112B and IEC 60034-2-1[10]. Countries without domestic motor manufacturing facilities import motors and use different testing procedures on imported motors. Recently introduced IEC 60034-30-1:2014 had been identified as the best to harmonize efficiency classes of electric motors all over the world. At the same time, with the IEC 60034-2-1:2007 standard, a new procedure for the measurement of motor efficiency has been introduced to replace different standards used by different nations in the world. At present, many countries have commenced following this IEC standard and have set the Minimum Energy Performance Standards (MEPS) [10] on their own or follow the European Union MEPS [11].

Sri Lanka does not have a labelling scheme to identify efficiency of industrial motors. The purpose of developing such a labelling system for industrial motors is to guide the users to purchase energy efficient industrial motors based on economic factors. Further, it helps in deciding the replacement or reuse of repaired or rewound motors. 


\section{Development of Energy Efficiency Testing System based on IEC standard (IEC 60034-2-1:2007)}

Three-phase induction motors used as the main electrical machinery play a vital role in industries. Single-phase induction motors are used in both industrial and non-industrial applications. Cage rotor induction motors are the most commonly used type of motors in industries. Wound rotor motors are used for special purposes.

\section{Determination of Efficiency from Direct Measure-} ment:

Torque measurement test (input-output measurement method)

Efficiency $\eta=\frac{P_{2}}{P_{1}}$

where $P_{1}$ is the input electrical power and $P_{2}$ is the output mechanical power.

Determination of Efficiency from indirect measurement:

Summation of separate losses

Efficiency $\eta=\frac{P_{1-} P_{T}}{P_{1}}$

where $P_{1}$ is the input electrical power and $P_{T}$ is the summation of total losses.

$$
\begin{gathered}
P_{T}=\text { constant } \\
\text { loss }\left(P_{K}\right)+\text { stator winding loss }\left(P_{S}\right) \\
+ \text { rotor winding loss }\left(P_{r}\right) \\
+ \text { additional load } \operatorname{loss}\left(P_{L L}\right)
\end{gathered}
$$

The additional load loss is calculated from residual losses $\left(P_{L r}\right)$

The direct or indirect efficiency measurement methods were adopted, and the methods of testing the efficiency of three-phase and single-phase induction motors have been proposed as per the IEC 60034-21, described in Table 1. Based on IEC 60034-2-1, a software program was developed for efficiency testing of three-phase cage rotor induction motors up to 2 MW and single-phase induction motors of any capacity.

Table 1 - Preferred Methods of Efficiency

Testing

\begin{tabular}{|l|l|l|l|}
\hline Method & Description & $\begin{array}{l}\text { Required } \\
\text { Tests }\end{array}$ & $\begin{array}{l}\text { Applica- } \\
\text { tion }\end{array}$ \\
\hline $\begin{array}{l}\text { Input- } \\
\text { output } \\
\text { method }\end{array}$ & $\begin{array}{l}\text { Torque Meas- } \\
\text { urement }\end{array}$ & $\begin{array}{l}\text { Dynamome- } \\
\text { ter test }\end{array}$ & $\begin{array}{l}\text { All single- } \\
\text { phase ma- } \\
\text { chines }\end{array}$ \\
\hline $\begin{array}{l}\text { Sum- } \\
\text { mation } \\
\text { of } \\
\text { losses; } \\
\text { Resid- } \\
\text { ual } \\
\text { losses }\end{array}$ & $\begin{array}{l}\text { Stray-load } \\
\text { losses from re- } \\
\text { sidual loss }\end{array}$ & $\begin{array}{l}\text { Rated load } \\
\text { test with } \\
\text { torque } \\
\text { Load curve } \\
\text { test with } \\
\text { torque } \\
\text { No-load test }\end{array}$ & $\begin{array}{l}\text { phase ma- } \\
\text { chines } \\
\text { with rated } \\
\text { output up } \\
\text { to 2 MW }\end{array}$ \\
\hline
\end{tabular}

Efficiency Testing of all Single-phase Motors

The preferred efficiency test method of single-phase motors is the input-output method. For this method, the dynamometer test is performed. In a dynamometer test, the test motor is coupled to a dynamometer. The dynamometer is calibrated, and the motor is operated at rated load and the required electrical and mechanical measurements are recorded. Motor efficiency is calculated from these values [7].

Efficiency Testing of Three-phase Motors (for rated output up to $2 \mathrm{MW}$ )

The preferred efficiency test method is the summation of separate losses. Additional load loss is determined by residual loss. Calculation of constant losses depends on the output of the no-load test.

This method determines the efficiency by the summation of separate losses; which are iron loss, windage \& friction losses, stator \& rotor copper losses and additional load losses. These tests are interconnected to each other and the test personnel should follow the instructions in the standards.

The required tests in order are the cold resistance measurement, rated load test, and load curve test, followed by the no-load test.

Constant losses depend on no-load test outputs, while the variable losses (stator \& rotor winding losses) depend on load curve test outputs. Residual losses depend on all test outputs [7]

\section{Efficiency Testing Software Development}

The LabView system design software was selected to develop the motor efficiency testing application. This is one of the most suitable design software platforms for simulating the test and validating the system. Figure 1 shows the Lab View interface developed.

\section{Figure 1 - LabView Interface}

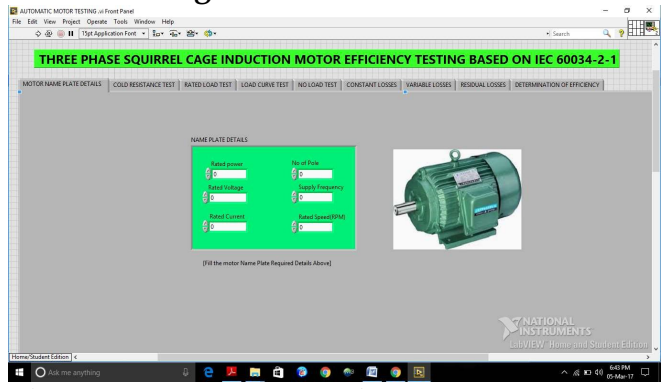

There are two main working environments in LabView, Front Panel window and the Block Diagram window. The Front Panel is used to create user interface functions such as user interface controls or indicators. The Block Diagram is used to build code using VIS and structures to control the Front Panel controls. After building the interface in the Front 
Panel, the codes are added using graphical representations of functions to control the Front Panel objects. The Block Diagram contains this graphical source code. The Front Panel object appears in the Block Diagram. Wiring tools are used to create the logic flow between the objects on the Block Diagram. Figure 2 shows the LabView Block Diagram.

Figure 2 - LabView Block Diagram

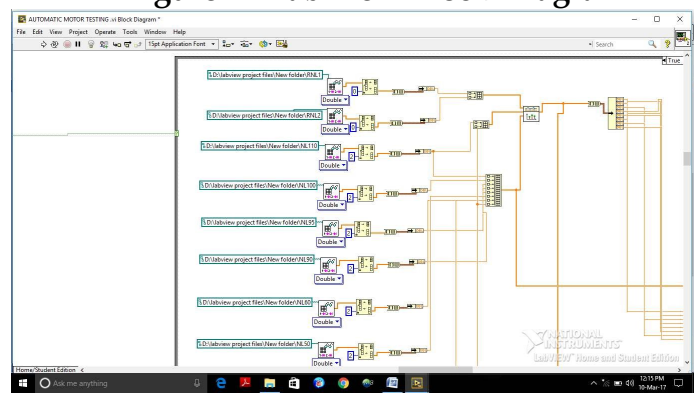

Data acquisition section of LabView involves gathering signals from measurement sources and digitalizing the signals for storage, analysis and display. The data acquisition hardware acts as the interface between computer and the other measurement sources.

LabView needs to read and save the input signals from sensors through the data acquisition hardware. Then the saved data is used for calculations. Figure 3 shows the sensor signal reading function.

Figure 3 - Sensor Signal Reading Function

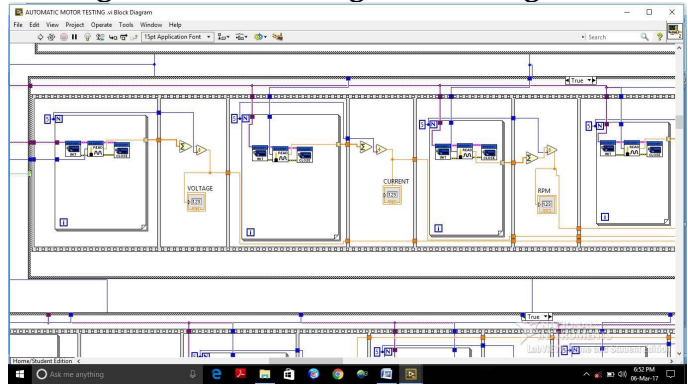

In LabView software, once the testing performance is completed, all the test results are saved in a spreadsheet. Those saved results are recalled for calculations from the spreadsheet. Results are displayed on the Front Panel after all calculations are completed. Figure 4 shows the LabView efficiency display interface.
Figure 4 - LabView Efficiency Display Interface

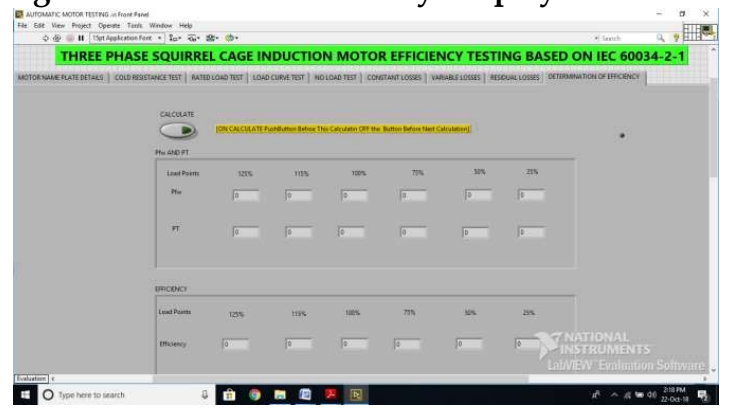

Test Bench Model Proposal

The efficiency test bench was developed using a simple design for easy performance, receipt of accurate measurements and to deliver accurate results. The proposed test bench designs are given in Figure 5 and Figure 6. This design was developed based on the requirements of IEC 60034-2-1 testing method.

Figure 5 - Proposed Design of Test Bench (Three-phase Induction Motor)

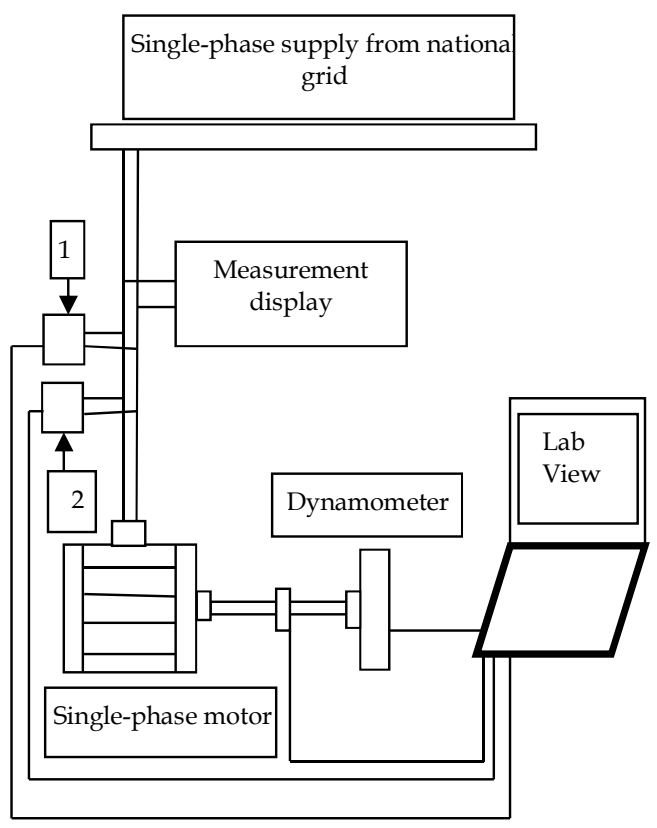

1: current \& voltage sensors, 2: auto transformer or variac, 3 : winding resistance measurement sensor, 4 : temperature sensors, 5: speed \& torque sensors, 6: data acquisition device 
Figure 6 - Proposed Design of Test Bench (Singlephase Induction Motor)

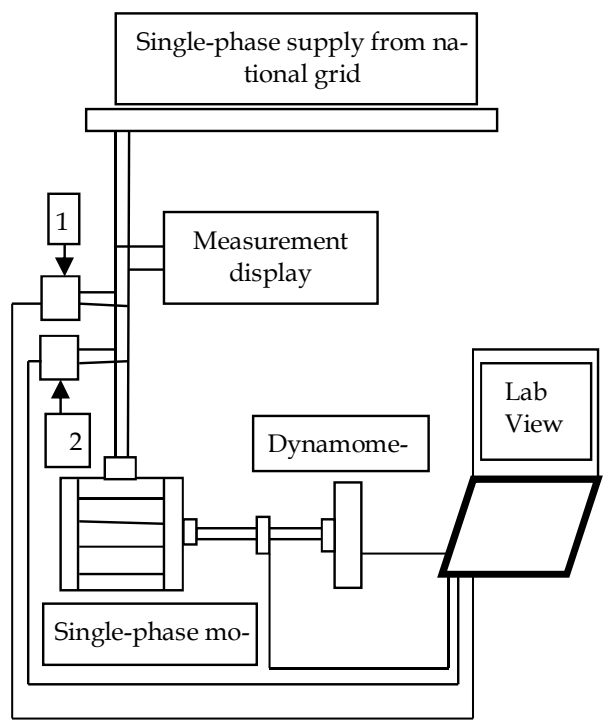

1: current sensor, 2: voltage sensor, 3: speed sensor The sensors of proposed test bench must meet the IEC defined accuracy level as given in the Table 2 .

Table 2 - Proposed Sensors for Test Bench

\begin{tabular}{|c|c|c|c|}
\hline Quantity & $\begin{array}{l}\text { IEC Re- } \\
\text { quired Ac- } \\
\text { curacy }\end{array}$ & $\begin{array}{l}\text { Suggested } \\
\text { Instrument }\end{array}$ & $\begin{array}{c}\text { Instrument } \\
\text { Accuracy }\end{array}$ \\
\hline Power & $\begin{array}{l}\text { Class } 0.2 \& \\
\text { overall un- } \\
\text { certainty of } \\
0.2 \% \text { of } \\
\text { reading at } \\
\text { power fac- } \\
\text { tor } 1.0 .\end{array}$ & $\begin{array}{l}\text { Yokogawa } \\
\text { WT1600 } \\
\end{array}$ & $\begin{array}{l} \pm 0.15 \% \text { of } \\
\text { reading at } 50 \\
\mathrm{~Hz}\end{array}$ \\
\hline Voltage & $\begin{array}{l}\text { Class } 0.2 \& \\
\text { overall un- } \\
\text { certainty of } \\
0.2 \% \text { of } \\
\text { reading at } \\
\text { power fac- } \\
\text { tor } 1.0\end{array}$ & \begin{tabular}{|l} 
\\
Yokogawa \\
WT1600
\end{tabular} & $\begin{array}{l} \pm 0.15 \% \text { of } \\
\text { reading }\end{array}$ \\
\hline & $\begin{array}{l}\text { Class } 0.2 \& \\
\text { overall un- }\end{array}$ & \begin{tabular}{|l|} 
Yokogawa \\
WT1600 \\
\end{tabular} & $\begin{array}{|ll|}\begin{array}{l} \pm \\
\text { reading }\end{array} \\
\end{array}$ \\
\hline Current & $\begin{array}{l}\text { certainty of } \\
0.2 \% \text { of } \\
\text { reading at } \\
\text { power fac- } \\
\text { tor } 1.0\end{array}$ & $\begin{array}{l}\text { Hitec CU- } \\
\text { RACC }\end{array}$ & $\begin{array}{l} \pm 0.01 \% \text { of } \\
\text { reading }\end{array}$ \\
\hline Torque & Class 0.2 & HBM T12 & Class 0.03 \\
\hline $\begin{array}{l}\text { Rota- } \\
\text { tional } \\
\text { speed } \\
\end{array}$ & $\pm 0.1 \mathrm{rpm}$ & HBM T12 & \begin{tabular}{|lr} 
Speed & reso- \\
lution & 0.1 \\
rpm & \\
\end{tabular} \\
\hline \multirow{2}{*}{$\begin{array}{l}\text { Tempera- } \\
\text { ture }\end{array}$} & \multirow{2}{*}{ $\pm 1 \mathrm{~K}$} & $\begin{array}{l}\text { Keithley } \\
2701 \\
\end{array}$ & $\pm 0.06^{\circ} \mathrm{C}$ \\
\hline & & $\begin{array}{l}\text { Pt } 100 \text { class } \\
\text { A }\end{array}$ & $\begin{array}{l} \pm(0.15 \\
+0.002 / \mathrm{t} /)^{\circ} \mathrm{C} \\
\end{array}$ \\
\hline
\end{tabular}

\begin{tabular}{|l|l|l|l|}
\hline & & $\begin{array}{l}\text { Pt 100 class } \\
\mathrm{B}\end{array}$ & $\begin{array}{l} \pm(0.30 \\
+0.005 / \mathrm{t} /)^{\circ} \mathrm{C}\end{array}$ \\
\hline $\begin{array}{l}\text { Re- } \\
\text { sistance }\end{array}$ & $\begin{array}{l}\text { Class 0.2 \& } \\
\text { over all un- } \\
\text { certainty of } \\
0.2 \% \text { of } \\
\text { reading }\end{array}$ & $\begin{array}{l}\text { Keithley } \\
2701\end{array}$ & $\begin{array}{l} \pm 0.01 \% \text { of } \\
\text { reading }\end{array}$ \\
\hline
\end{tabular}

To obtain accurate results, the sensors should be accurate as mentioned in Table 2. Therefore, such a commercially usable test bed should be developed.

\section{Financial Evaluation Model}

This financial evaluation model helps in decisionmaking when replacing a motor or upgrading a system. This model was developed based on industrial electricity tariffs in Sri Lanka [8] and considered all three industrial customer categories, I1, I2, and I3. It calculates the expected savings and the payback period.

Figure 7 - A Sample of Developed Economic Calculation Models
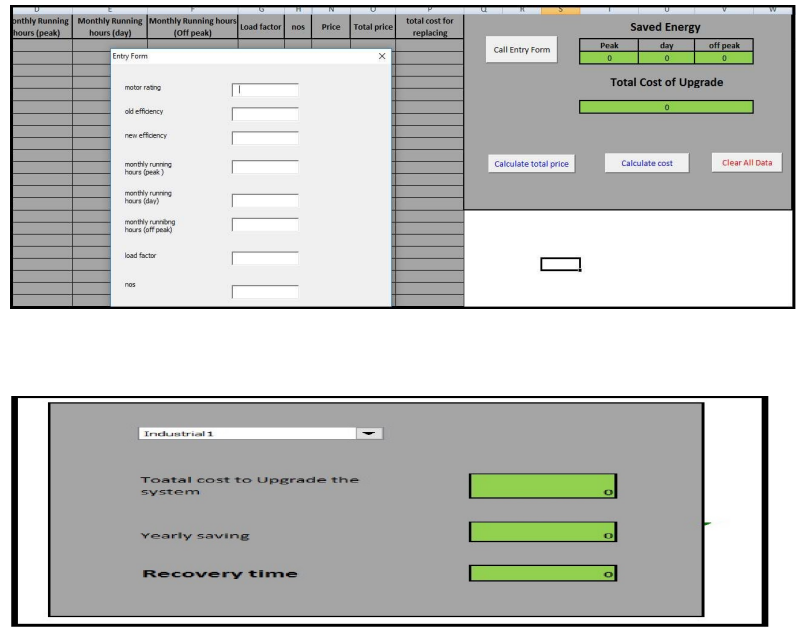


\section{Decision Making Process}

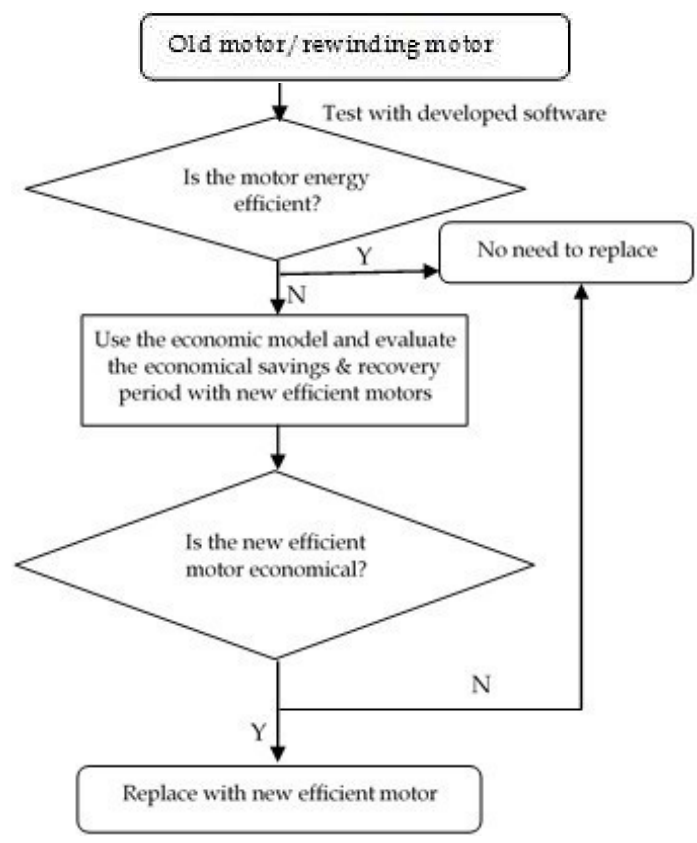

\section{Conclusion}

Sri Lanka has not yet adopted a labelling system for industrial motors to indicate their energy performance. The paper describes an effort taken to facilitate a labelling system for industrial motors. The study is mainly to develop the efficiency testing software and a basic test bed for industrial motors based on IEC 60034-2-1 standard. An economic model is developed to assist in decision-making for upgrading motors with higher efficiency motors. Presently, many countries have developed industrial motor labelling systems based on IEC standard (IEC 600342-1) or other standards.

The testing procedure was developed on LabView software platform and verified with manual calculations. The financial evaluation model was developed based on the industrial electricity tariff structure in Sri Lanka, keeping provisions for any future tariff changes. This model was developed mainly to decide the financial benefits of selecting new motors or to decide on replacement of existing low efficiency motors. It is recommended to calculate the efficiencies of old motors and new motors using the efficiency test program developed.

The test bench model is the most important part of efficiency testing. A model with accurate equipment is essential for reliable results. Development of the test bench with accurate sensors and other equipment is recommended as future work.

\section{References}

1. "A Case Study of Determining Energy Efficiency in Squirrel Cage Induction Motor" [Online]. Available: http://www.icrepq.com/icrepq\%2716/374-16-esen.pdf

2. "converter-fed induction motor losses: determination with IEC methods"[Online]. Available: https://www.doria.fi/bitstream/handle/10024/113916 /Karkkainen_Hannu_MSc_FINAL.pdf? sequence $=2$

3. "Indian standard Rotating Electrical machine part2. method of tests," [Online]. Available: https://www.scribd.com/document/344786082/is15999-2-1-2011-pdf

4. "Premium Efficiency motor selection and application guide" [Online]. Available: $h$ https://energy.gov/sites/prod/files/2014/04/f15/amo_ motors_handbook_web.pdf

5. "Energy efficiency test methods for three phase induction motors" [Online]. Available: https://archive.org/details/gov.law.csa.c390.1993

6. "Comparative analysis if IEEE 112-B and IEC 34-2 Efficiency Testing Standard" [Online].Available: http://www.joinville.udesc.br/portal/professores/faria s/materiais/00966506.pdf

7. "Guide for the use of Electric motor testing methods based on IEC 60034-2-1," [Online]. Available: https://www.motorsystems.org/files/otherfiles/0000/0 113/guide_to_iec60034-2-1_may2011.pdf

8. Sri Lankan industrial Electricity Tariff. [Online]. Available: http://www.ceb.lk/for-your-business/

9. Sri Lankan Energy Balance statistics. [Online]. Available: (www.ifo.energy.gov.lk)

10. minimum energy performance standards MEPS for electric motors in global markets[Online] Available: https://www.motorsystems.org/files/otherfiles/0000/0100/meps_guide_feb2009.pdf

11. Harmonized Standards for Motors and Systems [Online] Available: https://www.motorsystems.org/files/otherfiles/0000/0080/brunner_global_progress_12092011.pdf

12. World Energy Outlook 2007 pdf reference [online] Available: https://webstore.iea.org/world-energyoutlook-2007 